\title{
Introduction
}

\section{Geoffrey M. Hodgson*}

The book is the first of what is hoped to be a series of readers produced by the European Association for Evolutionary Political Economy (EAEPE) through Edward Elgar Publishing. The aim of these volumes is to present an exciting and diverse body of work in economics and related disciplines, to undergraduate students, graduate students and lecturers. Much of this work is not discussed in standard textbooks. Yet it is of enormous importance in understanding the manifest turbulence and transformations in the modern world.

With the exception of the present introduction, the essays reprinted here have all been published before. They all appeared in collections of papers presented at successive EAEPE conferences and workshops since 1990. In compiling this reader, key papers have been selected from conference volumes between 1990 and 1996 inclusive. ${ }^{1}$ The papers have been selected not simply on their merit and importance but also to provide a coherent structure for the reader as a whole. Furthermore, the specific focus of this reader is on 'key concepts' and that too is reflected in the choice of papers.

The first aim of this introductory essay is to place these essays in the historical and theoretical background of recent developments in economics and other social sciences. In recent years there have been enormous changes, especially within and on the fringes of economics itself. Some of these developments are sketched in section 1. Section 2 outlines the conceptual and theoretical foundations of institutional and evolutionary economics. Section 3 briefly summarizes the contents of the essays reprinted here.

\section{ECONOMICS FROM THE 1970s TO THE 1990s}

If we could travel back in time just a few years to 1970, we would be struck by the remarkable difference between economics as taught then and as taught today. First, although the formalization of mainstream economics was then proceeding apace, it had not reached the levels that we find now. In the 1970s, even prestigious journals such as the American Economic Review and the 
Economic Journal carried a significantly lower proportion of mathematical articles.

Second, non-mainstream viewpoints within economics had a stronger following and could be found in many university departments of economics. 'Post Keynesian' economics was launched in the early 1970s by Joan Robinson, Alfred Eichner, Sidney Weintraub and Paul Davidson (Lee, 2001). Within this grouping, a minority were engaged in the famous 'Cambridge' debates over capital theory (Harcourt, 1972). It seemed to many at the time that a major theoretical flaw in mainstream economics had been identified. However, the main preoccupation of Post Keynesianism was macroeconomics. In addition, Marxian economics experienced a major global revival, partly as a consequence of the political radicalization of the student movement. Accordingly, during the 1970s, economics included sizeable non-mainstream tendencies, such as Marxism and Post Keynesianism.

Herbert Simon was awarded the Nobel Prize for economics in 1978, and his criticisms of mainstream economics became more influential. In addition, Nicholas Georgescu-Roegen (1971) published an important theoretical work with major implications for both economic theory and policy. Friedrich Hayek received the Nobel Prize in 1974 and this heralded a revival of 'Austrian' economics, particularly in the United States. Economists of the Austrian school were highly critical of the informational assumptions and equilibrium analyses of mainstream economics. However, unlike most other critics of mainstream economics, they promoted a highly pro-market policy agenda. This helped them to survive in the 1980s, in the ideological environment of Ronald Reagan and Margaret Thatcher.

Several important developments occurred within mainstream economics in the 1970s, of which a few can be mentioned. In microeconomics, neoclassical approaches remained dominant, with their common emphasis on rationality, maximization and equilibrium. In some respects there was a growing selfconfidence in this approach, with theorists such as Gary Becker applying it to new areas of enquiry such as the family. The perceived cutting edge of neoclassical theory was general equilibrium analysis. However, in the 1970s, general equilibrium theorists such as Gerard Debreu, Rolf Mantel and Hugo Sonnenschein discovered severe problems within this approach. These problems would eventually prove fatal for this research programme (Kirman, 1989; Rizvi, 1994a).

Another striking event in the 1970s was the inauguration of the 'new institutional economics'. The term was coined by Oliver Williamson (1975) and was also broadly associated with work from a variety of viewpoints by Ronald Coase, Douglass North, Mancur Olson, Richard Posner and others. These were important developments, not least because they opened for analysis the 'black box' of the firm and other institutions. 
In macroeconomics, perhaps the most significant mainstream development in the 1970s was the renewed assault on all varieties of Keynesianism. It was argued that Keynesian theory involved 'ad hoc' assumptions, and instead macroeconomics should be placed on the 'sound microfoundations' of general equilibrium theory (Weintraub, 1979). Milton Friedman promoted his own version of monetarism as an alternative to Keynesianism. The 'new classical economics' of Robert Lucas and others also became prominent.

The ideological climate changed markedly in the late 1970s. On the whole, Marxian economics failed to extricate itself from its arcane doctrinal debates and lost its theoretical momentum by the early 1980s. The only significant grouping of Marxian economists to survive the 1980s were those - such as John Roemer and John Elster - who had openly embraced mainstream theoretical and mathematical tools, such as neoclassical equilibrium analysis and game theory.

As a result, the 1980s opened with the main non-mainstream approaches to economics in difficulties. Post Keynesianism was under severe attack from the monetarists and Marxism was in severe decline. The Cambridge critique of the neoclassical aggregate production had been largely ignored. Frank Hahn (1982) rightly pointed out that the Cambridge critique of capital theory does not apply to disaggregated approaches such as general equilibrium theory. In these new circumstances, no school of non-mainstream economics made much headway.

Furthermore, mainstream economics itself, dramatically but quietly, shifted its cutting edge from general equilibrium theory to game theory. This became the main theatre of theoretical controversy within mainstream economics (Rizvi, 1994b).

At the same time, new critiques and alternatives began to develop. On the fringes, there was a steady increase in both 'evolutionary' and 'institutional' themes in the 1980s. Kenneth Boulding's (1981) book Evolutionary Economics appeared as one of the first of many in this new evolutionary wave. It was followed quickly by the classic work of Richard Nelson and Sidney Winter (1982) An Evolutionary Theory of Economic Change. These and other works brought into the limelight a very different type of approach to economic theory and analysis.

At roughly the same time, and especially in France, the régulation school had come into being through a work published originally in French in 1976 by Michel Aglietta (1979). In the 1980s, the régulation approach provided a bridge between Marxism and some newer evolutionary and institutionalist themes.

Also during the 1980s, there were significant developments in both the 'new' and the 'old' institutionalism. While the new institutionalism proved increasingly influential, some of its followers made links with the Austrian 
school, establishing links with the work of Carl Menger and subsequent Austrians (Schotter, 1981; Langlois, 1986).

In North America, a small group of 'old' institutionalists had formed the Association for Evolutionary Economics and the Journal of Economic Issues in the 1960s. While the old institutionalists had been overshadowed by Marxism and Post Keynesianism in the 1970s, the new situation in the 1980s provided the old institutionalists with an opportunity. After all, developments within or close to mainstream economics had put institutions back on the agenda. In addition, through the efforts of Americans such as Warren Samuels (1979), Marc Tool (1979) and others, the 'old' institutional economics began once again to be noticed. In addition, the Association for Institutionalist Thought was founded in the early 1980s. It continues to meet alongside the gatherings of the Western Economic Association in the USA.

These initiatives helped to revive interest in the works of such institutionalists as Thorstein Veblen, Wesley Mitchell, John Commons and Clarence Ayres. Significantly, several of their books were reprinted in the 1980s and 1990s. The most important living representative of the American institutionalist tradition - John Kenneth Galbraith - had already achieved prominence through his popular and challenging works.

The Santa Fe Institute was founded in 1984. It had an impact on the development of complexity theory and promoted non-reductionist discourses in both the social and the natural sciences (Waldrop, 1992). Another important and fertile development in the 1980s was the growth in interest in the methodology of economics, stimulated by publications such as those by Mark Blaug (1980) and Bruce Caldwell (1982).

The year 1988 was marked by a remarkable number of influential publications and developments. An influential work by Amitai Etzioni (1988) led to the foundation of the Society for the Advancement of Socio-economics (SASE). Horst Hanusch (1988) produced an edited volume on Evolutionary Economics that signalled a strong revival of interest in the ideas of Joseph Schumpeter and the formation of the International Joseph Schumpeter Association. A larger, seminal collection of essays - edited by Giovanni Dosi, et al. (1988) - focused on technical change and also proclaimed some strong 'evolutionary' themes. Finally, a work of mine may have helped the revival of the old institutional economics in Europe and America (Hodgson, 1988). The European Association for Evolutionary Political Economy was conceived at a meeting near London in 1988. It emerged as a broadly based and pluralist forum for the development of institutional and evolutionary economics.

Between 1980 to 1990 , the profile of non-mainstream economics had changed globally and dramatically. In 1980, dissident economics was dominated by macroeconomics of Marxist and Post Keynesian hues. By contrast, 
in 1990, the picture was much more diverse. It involved unorthodox developments in microeconomics as well as in macroeconomics, and it included novel and prominent evolutionary and institutionalist themes.

However, in the meantime, mainstream economics had become more formal and narrow. Several departments of economics that had formerly accommodated non-mainstream economists, were by 1990 entirely under mainstream control. This was particularly noticeable at the University of Cambridge. Its leading non-mainstream theorists, Nicholas Kaldor, Joan Robinson and Piero Sraffa, all died in the 1980s. By 1990 the department was under neoclassical control. Similar changes occurred at many other institutions, including Rutgers University in New Jersey, which had previously been a Post Keynesian citadel.

After the fall of the Berlin Wall in 1989 and the end of the Cold War, the ideological environment changed. An important effect of this was to create more space within mainstream economics for analyses of the limitations of the market mechanism and justifications for some forms of state intervention. In addition to the extreme pro-market views that were still propounded in Chicago and elsewhere, rising mainstream theorists such as Joseph Stiglitz and Paul Krugman defended some role for state intervention and the regulation of markets. A wider variety of ideological viewpoints could be found among leading mainstream economists. The mistaken view that the debate between mainstream and dissident economics was primarily over ideology or policy was undermined.

However, what was noticeable about this ideological shift within the mainstream was that all positions had to be articulated within the increasingly formal language of mathematical economics, with less attention than in the 1970s to real world institutions and history. Although mainstream economics itself had changed enormously in the period, it increasingly defined itself in narrow, formalistic terms.

As a result, many non-mainstream economists were excluded from mainstream departments and journals. Institutional and evolutionary economists did not entirely reject mathematics as a tool, but they were critical of the tendency of the mainstream to become immersed in mathematical technique for its own sake. Consequently, many non-mainstream economists working in this area found employment in business schools, science policy units, departments of public policy and so on. Important work on the nature of social institutions was also carried out in social theory and philosophy (Searle, 1995). These matters of disciplinary demarcation affected the development of both mainstream and non-mainstream economics in the 1990s.

Institutional and evolutionary economics developed a broad global network, with a particular concentration in Europe. As well as important theoretical developments, it had an impact on economic policies, particularly 
in the areas of technology policy, innovation policy, competition policy and corporate strategy. Several governments in Europe had advisors who were particularly inspired by these approaches. As the millennium drew to a close, it was clear that institutional and evolutionary economics had had a major impact, and it faced exciting new challenges for the next century.

In addition, important developments within mainstream economics pointed to issues raised already by the dissident economists. For example, Douglass North (1990) and Masahiko Aoki (2001) moved towards more open-ended and evolutionary theoretical analysis. The idea that all theory has to start simply from given individuals was abandoned by some. Instead, individuals were placed in a historical and institutional context. This work led to a degree of convergence with the evolutionary ideas of the 'old' institutionalists.

\section{THE HISTORICAL AND THEORETICAL FOUNDATIONS OF INSTITUTIONAL AND EVOLUTIONARY ECONOMICS}

Indeed, the developments in the last three decades of the twentieth century generally helped to rehabilitate the approaches of the historical school and the 'old' institutionalists. The historical school prevailed in Germany from the 1840s to the 1940s. The 'old' institutionalists were dominant in America between the First and Second World Wars. Within these schools of thought, evolutionary and institutional themes were common. These former schools still provide quarries of ideas. Their systems of thinking were not centred on, nor overly encumbered by, the neoclassical concepts of rationality, maximization and equilibrium.

Both American institutionalism and German historicism were immense and diverse movements and it is impossible to summarize their ideas in detail here. What should be emphasized, however, is that they held to a conception of economics that was much broader than the idea of the subject promoted by mainstream economists today. Within their capacious conception of the subject a number of important theoretical themes can be found. Some of these themes have been revived in modern institutional and evolutionary economics today.

\section{Historical Specificity}

Modern institutional and evolutionary economists endorse a theme that has been prominent in the writings of American institutionalists, German historicists and Marxists. From their viewpoints, it is recognized that socio-economic systems have changed substantially and enormously through history and that 
there are also important variations between different socio-economic systems at any point in time. From a realist point of view, changes and differences in reality have implications for the type of theory to be developed (Mäki, 1989; Lawson, 1997). Consequently, attempts to create general or universal theories in social science face the problem of dealing with this real variation and diversity. General theorizing faces an ontological constraint. Attempts to erect general theories in social science have either failed in their own terms to be truly general, or have acquired highly limited explanatory powers (Hodgson, 2001).

As a result, economic and social theorists are obliged to build theories that in part involve historically or geographically specific assumptions. Although all theorizing involves some general categories and elements, effective theories also involve specific and particular assumptions. Marx recognized this in his analysis of capitalism. The German historical school developed methods and taxonomies to deal with particular historical developments. The American institutionalists focused on the nature of specific economic institutions. These schools recognized that the value of any general theory in social science is, at best, highly limited. Instead their focus was on particular systems, institutions and mechanisms.

Similarly, the essays in the present volume do not pursue the chimera of a purely universal theory. Of course, some general concepts - such as knowledge, power, evolution and open systems - are thematic for institutional and evolutionary economics. But an attempt is made to link their exposition to real economic processes and relations. For example, it is important to understand and explain key phenomena such as prices, but the exposition of price theory in large part depends on the analysis of historically and institutionally specific market relations and pricing mechanisms. In addition, markets are not the universal ether of all human interaction but a highly specific type of social formation. In short, markets themselves are historically specific institutions.

\section{Evolutionary Orientation}

In contrast to the traditional equilibrium and steady-state orientation of much economic theory, institutional and evolutionary economists place much greater emphasis on processes, changes and structural transformations. The recognition of the historical specificity of socio-economic systems itself points to the processes of evolution and system change through time. While much of economic theory attempts to focus principally on that which is common to all socio-economic systems, institutional and evolutionary economics also emphasizes the differences and the changes in socio-economic systems.

Of course, all theorizing must take some items as given. But from an evolutionary perspective a theorist is obliged to give some justification and 
explanation of the assumptions that are made. If assumptions are made about human individuals or social institutions, then the theorist is obliged to point to a plausible evolutionary or historical explanation of the origin of the assumed circumstances. If no such explanation is yet available, then as scientists we are obliged to place this omission on the agenda for future enquiry.

For example, if humans are assumed to be capable of rational deliberation then we have to provide, at least in outline, an evolutionary explanation of such capacities. Rationality cannot be assumed to have dropped from heaven during some stage of human evolution. Consequently, we required some evolutionary picture, similar to the one developed by William James (1890) and others, in which reason is built upon habit, and in turn habit is built upon instinct. In practice, as the institutional economist John Maurice Clark (1918, p. 26) put it: 'it is only by the aid of habit that the marginal utility principle is approximated in real life'. Even if agents are rational according to the assumptions of neoclassical economics, then their capacity to be rational itself depends upon prior habituation. In humans, reason evolved after habits, and all human reason is dependent upon prior habits.

Essentially, a commitment to evolutionary explanation involves an ongoing quest for causal explanations. Of course, the process of enquiry can never be complete and explanations are always limited. All explanation involves theoretical isolation or abstraction (Mäki, 1992). It is impossible to bring every real causal link into the theoretical picture. Nevertheless, the evolutionary commitment remains. The obligation is to push back the boundaries of explanation, and not to be satisfied with abstractions simply on the basis of their apparent elegance or mathematical appeal.

The recognition that scientific enquiry can never reach finality or closure encourages a tolerant attitude to the conduct of science. The fact that all theory is necessarily incomplete and provisional obliges the scientist to accept, in principle, the viability of some alternative explanation. Like evolution in the real world, science itself thrives on diversity and plurality (Salanti and Screpanti, 1997).

A reason why the boundaries of explanation are never all-embracing is that open, complex systems exhibit novelty (Witt, 1992). Complex interactions and exchanges within and across the boundaries of the system bring about novel, emergent and unpredictable forms and events. Variation and diversity are part of both the natural and the economic order (Saviotti, 1996; Metcalfe, 1998). As the institutionalist and historicist John Atkinson Hobson (1936, p. 216) put it: 'Emergent evolution brings unpredictable novelties into the processes of history, and disorder, hazard, chance, are brought into the play of energetic action'.

The ongoing quest for causal explanations has another important implication. Given that there is no finality in each chain of cause and effect, and in 
principle there are no limits to the probing extent of scientific enquiry, then economists must also be concerned with the interactions between the social and the natural domain. There are no hermetic analytical boundaries between the social and the natural world. All socio-economic systems are embedded in, and dependent upon, a natural environment. Accordingly, the interactions between socio-economic and ecological systems, including effects such as pollution and ecological degradation, have to be taken into account (GeorgescuRoegen, 1971).

The extent to which evolutionary principles or laws from the natural world also apply to society and the economy has long been a matter of controversy among evolutionary and institutional economists (Penrose, 1952; Campbell, 1965). However, the adoption of a view that some laws or principles may apply across both the social and the natural domain does not itself imply that explanations of social and economic phenomena have themselves to be reduced to biological terms (Hodgson, 1993). The prevailing view among institutional and evolutionary economists is that socio-economic systems are governed by principles that are not entirely reducible to those pertaining to the natural world.

As the institutional and evolutionary economist Thorstein Veblen (1909, p. 300) put it, if conventions and institutions were mere outcomes - not the principal basis of social action - and instead people acted 'solely and directly on the grounds and values afforded by the unconventionalised propensities and aptitudes of hereditary human nature, then there would be no institutions and no culture'. The socio-economic domain has emergent properties and causal powers that are not reducible to biology, just as biology itself is not completely reducible to physics or chemistry.

\section{Encultured Individuals}

The general implication of the ongoing quest for causal explanations is that no entity is ultimately taken as given. This importantly applies to the human individual. In contrast, mainstream economists have typically taken the individual as given. In particular, Menger and the new institutionalists have been committed to the theoretical project of explaining the emergence of institutions in terms of the interactions of given individuals alone, starting from an institution-free 'state of nature'. It has been suggested above that this project has insurmountable internal theoretical problems (Hodgson, 1998a).

Among these difficulties is the problem of incorporating some notion of learning into the notion of fixed preferences. Although some attempts have been made to reconcile learning with Bayesian or other conceptions of rationality, the fundamental problem is that learning, if real and substantial, must in part reconstitute the preferences or purposes of the individual (Nonaka and Takeuchi, 1995; Nooteboom, 2000). 
The tradition of institutional and evolutionary economics that is promoted here does not confine itself to the 'upward causation' from individuals to institutions. Although institutions clearly depend upon the actions of individuals, in addition individuals are affected by their institutional environment. There is 'downward causation' as well. Just as institutions are constituted by individuals, individuals are constituted by institutions (Giddens, 1984; Archer, 1995). Accordingly, Veblen (1898, p. 389) criticized Menger and others for assuming 'a passive and substantially inert and immutably given human nature'.

The idea that individuals are moulded by circumstances is thematic to the old institutionalism and follows from a commitment to an evolutionary approach (Hodgson, 2000). Individual preferences and purposes can be affected by behaviours, experiences, cultures and institutions. Instead of the atomistic individual, institutional and evolutionary economists focus on the social and encultured individual.

Consider a relevant example. Trust is an interpersonal relationship of some economic significance. Trust is an emergent property of an enduring and reciprocal relationship between multiple individuals in an institutional context. It is a relational property; not something that is a property of isolated individuals. Accordingly, the environment of trust, or lack of it, affects individual aims and preferences. The study of the role of trust in corporate organizations is an important area of research today (Lazaric and Lorenz, 1998; Nooteboom et al., 1997).

Of course, once we adopt the view that there can be 'downward causation' from institutions and other entities at a 'higher' level to individuals then one is obliged to explain the causal mechanisms involved. Mere mention of cultural or social 'forces' is not enough. The danger is that the greater emphasis will be put on 'downward causation', to the neglect of the individual and causality in the opposite direction. The causal relationship between actor and structure remains an enduring problem in all the social sciences.

The argument of Veblen (1899, p. 192) and those inspired by him was that institutions acted upon individuals by changing their habits. Furthermore: 'Social structure changes, develops, adapts itself to an altered situation, only through a change in the habits of thought of the several classes of the community; or in the last analysis, through a change in the habits of thought of the individuals which make up the community'. Once again the concepts of habit and routine are central to evolutionary and institutional economics.

\section{Multiple Levels of Analysis}

Once we abandon the false dichotomy of methodological individualism (in which explanations of social phenomena are reduced to the preferences and 
purposes of individuals alone) and methodological collectivism (in which explanations of social phenomena are reduced to the collectives, structures, cultures or institutions alone) then the way is open to explore a third perspective, involving the interaction of individual and structure.

The old institutionalists took institutions as well as individuals as units of analysis. According to the argument pursued here, taking institutions as well as individuals as units of analysis should exclude a reductionist approach in which explanations of one are reduced entirely to the terms of the other. Both types of unit of analysis should come into the picture.

It has already been noted that Veblen saw the institutional and cultural, the individual, and the biological, all as legitimate levels of analyses. But in his view no level was entirely reducible to another. This multi-levelled approach has since been thematic in institutional and evolutionary economics.

For example, in his 1924 Presidential Address to the American Economic Association, Mitchell - a former student of Veblen - argued that economists need not begin with a theory of individual behaviour but with the statistical observation of 'mass phenomena'. Mitchell (1937, p. 30) went on: 'The quantitative workers will have a special predilection for institutional problems, because institutions standardize behavior, and thereby facilitate statistical procedure'. Subsequently, Rutledge Vining (1949, p. 85) noted how 'much orderliness and regularity apparently only becomes evident when large aggregates are observed' and noted the limitations of a reductionist method in economics. Modern computer simulations and other studies of complex systems seem to underline similar points (Cohen and Stewart, 1994; Chiaromonte and Dosi, 1993).

Mitchell and his colleagues in the US National Bureau for Economic Research in the 1920s and 1930s played a vital role in the development of national income accounting and suggested that aggregate, macroeconomic phenomena have an ontological and empirical legitimacy. Arguably, this important incursion against reductionism created space for the Keynesian revolution in economics. Through the development of national income accounting, the work of Mitchell and his colleagues helped to establish modern macroeconomics and inspired the macroeconomics of Keynes (Mirowski, 1989, p. 307; Colander and Landreth, 1996, p. 141). Accordingly, a consequence of the Veblenian emphasis on multiple levels of analysis was the legitimation of a macroeconomics that could not be reduced entirely to microeconomic elements.

Similarly, the German historical school had previously established a level of analysis of the 'national economy'. As Christopher Freeman (1995) and others have noted, this historicist work is a root of the modern study of 'national systems of innovation' (Lundvall, 1992; Nelson, 1993). Clearly, once we adopt the idea of multiple levels of analysis, additional levels are possible, such as the firm, the industry, the region and the global economy. 
The 'old' institutional economics did not attempt to build up a picture of the whole system by moving unidirectionally from given individuals. Instead there is the idea of interactive agents, mutually entwined in durable and selfreinforcing institutions. This provides a quite different way of approaching the problem of theorizing the relationship between actor and structure.

\section{THE CONTENTS OF THIS READER}

This volume is intended to provide introductions to, and illustrations of, some of the key themes touched upon in this introductory essay.

Part I focuses on key concepts such as learning, power, trust, prices and markets. In Chapter 1, Marc R. Tool provides a survey of institutionalist works on pricing theory. Not only does this essay refute the allegation that the 'old' institutional economics was 'atheoretical' or 'against theory', but also it shows that institutionalist theories of pricing are rooted in an analysis of the institutional routines and market conditions associated with the pricing process.

In Chapter 2 Bengt-Åke Lundvall examines the challenge that the concept of learning provides to mainstream economics. He dramatizes this argument in the context of the modern, knowledge-intensive, learning economy.

In Chapter 3 David Young examines different conceptions of power in economic analysis. Building on earlier work by Steven Lukes (1974) and others, Young shows that much economic and social theory relies on an overly limited conception of power. In contrast, an enhanced concept of power involves a reconstitution of the aims and purposes of those individuals over whom power is exercised.

In chapter 4, Sandye Gloria-Palermo examines the Austrian view of the market process and finds it deficient in its treatment of creativity and novelty. This argument has important implications for the institutionalist understanding of markets (Gloria-Palermo, 1999).

In Chapter 5, Hans Berger, Niels G. Noorderhaven and Bart Nooteboom report an important and pioneering empirical study of the role of trust in economic relationships.

Part II is devoted to varieties of economic theory. It has a more specific focus, involving comparisons between schools of thought and the general role of theoretical pluralism in economic science. In Chapter 6 Benjamin Coriat and Giovanni Dosi offer a forensic examination and comparison of the 'regulationist' (or régulationniste) and 'evolutionary' research programmes, focusing especially on their strengths and complementarities.

In Chapter 7 Uskali Mäki discusses the relationship between the realist commitment to the existence of a real world outside ourselves and the exist- 
ence of multiple theories describing that single world. He shows that the possible relationships between different theories include complementarity and incompatibility.

Sheila C. Dow further explores this methodological theme in Chapter 8. She argues that the methodological pluralism of Bruce Caldwell (1982) and others, at least in a pure form, is untenable as a basis for knowledge. Further, the justification of methodological pluralism becomes opaque when it is combined with a unitary, closed-system epistemology or ontology.

Part III of this book is devoted to varieties of capitalism. In Chapter 9 Eileen Appelbaum and Ronald Schettkat analyse and compare different growth regimes, both through time and in different capitalist countries. They focus in particular on the impact of different wage-bargaining institutions on economic performance.

In Chapter 10, Bernard Chavance and Eric Magnin examine the evolution of some of the transitional economies in Central Europe in the 1990s. They show that the outcomes were highly dependent both on the particular national historical legacies and the types of privatization arrangement, financial institutions and industrial structures that were promoted by the early transition governments. Hence, despite the pressures of market globalization, highly diverse capitalist economies have emerged in Central and Eastern Europe.

Finally, in Chapter 11, Geoffrey M. Hodgson places the manifest variety of capitalist forms alongside a number of theoretical approaches. He argues that neoclassical, Austrian and Marxist approaches all have theoretical problems in fully recognizing and dealing with this institutional and cultural variety. He sketches an institutional approach to this problem that is directed at overcoming some of these limitations and defects.

\section{NOTES}

* The author is very grateful to Eileen Appelbaum, Albert Jolink, Uskali Mäki, Bart Nooteboom and Marc Tool for helpful comments on an earlier draft of this essay.

1. The complete list of volumes for the 1990-96 EAEPE conferences are: from the 1990 conference in Florence - Amin and Dietrich (1991) and Hodgson and Screpanti (1991); from the 1991 conference in Vienna - Blaas and Foster (1992); from the 1992 conference in Paris - Delorme and Dopfer (1994); from the 1993 conference in Barcelona Groenewegen et al. (1995) and Tylecote and van der Straaten (1997); from the 1994 conference in Copenhagen - Nielsen and Johnson (1998); from the 1994 workshop in Bergamo - Salanti and Screpanti (1997); from the 1995 conference in Krakow - Amin and Hausner (1997); from the 1996 conference in Antwerp - Michie and Reati (1998) and Groenewegen and Vromen (1999). The essays reprinted here have been slightly revised and updated. 


\section{REFERENCES}

Aglietta, Michel (1979), A Theory of Capitalist Regulation: The US Experience, translated by David Fernbach from the French edition of 1976, London: NLB.

Amin, Ash and Michael Dietrich (1991), Towards a New Europe? Structural Change in the European Community, Aldershot: Edward Elgar.

Amin, Ash and Jerzy Hausner (eds) (1997), Beyond Market and Hierarchy: Interactive Governance and Social Complexity, Cheltenham: Edward Elgar.

Aoki, Masahiko (2001), Toward a Comparative Institutional Analysis, Cambridge, MA: MIT Press.

Archer, Margaret S. (1995), Realist Social Theory: The Morphogenetic Approach, Cambridge: Cambridge University Press.

Blaas, Wolfgang and John Foster (eds) (1992), Mixed Economies in Europe: An Evolutionary Perspective on Their Emergence, Transition and Regulation, Aldershot: Edward Elgar.

Blaug, Mark (1980), The Methodology of Economics: Or How Economists Explain, 1st edition, Cambridge: Cambridge University Press.

Boulding, Kenneth E. (1981), Evolutionary Economics, Beverly Hills, CA: Sage Publications.

Caldwell, Bruce J. (1982), Beyond Positivism: Economic Methodology in the Twentieth Century, London: Allen \& Unwin.

Campbell, Donald T. (1965), 'Variation, selection and retention in sociocultural evolution', in Barringer, H.R., Blanksten, G.I. and Mack, R.W. (eds), Social Change in Developing Areas: A Reinterpretation of Evolutionary Theory, Cambridge, MA: Schenkman), pp. 19-49. Reprinted in General Systems, 14, 1969, pp. 69-85 and in Hodgson (1998b).

Chiaromonte, Francesca and Giovanni Dosi (1993), 'Heterogeneity, competition, and macroeconomic dynamics', Structural Change and Economic Dynamics, 4(1), June, pp. 39-63.

Clark, John Maurice (1918), 'Economics and modern psychology' Parts I and II, Journal of Political Economy, 26(1-2), January-April, pp. 1-30, 136-66. Reprinted in John Maurice Clark (1967), Preface to Social Economics, New York: Augustus Kelley, and in Hodgson (1998b).

Cohen, Jack and Ian Stewart (1994), The Collapse of Chaos: Discovering Simplicity in a Complex World, London and New York: Viking.

Colander, David C. and Harry Landreth (eds) (1996), The Coming of Keynesianism to America: Conversations with the Founders of Keynesian Economics, Aldershot: Edward Elgar.

Delorme, Robert and Kurt Dopfer (eds) (1994), The Political Economy of Diversity: Evolutionary Perspectives on Economic Order and Disorder, Aldershot: Edward Elgar.

Dosi, Giovanni, Christopher Freeman, Richard Nelson, Gerald Silverberg and Luc L.G. Soete (eds) (1988), Technical Change and Economic Theory, London: Pinter.

Etzioni, Amitai (1988), The Moral Dimension: Toward a New Economics, New York: Free Press.

Freeman, Christopher (1995), "The "national system of innovation" in historical perspective', Cambridge Journal of Economics, 19(1), February, pp. 5-24.

Georgescu-Roegen, Nicholas (1971), The Entropy Law and the Economic Process, Cambridge, MA: Harvard University Press. 
Giddens, Anthony (1984), The Constitution of Society: Outline of the Theory of Structuration, Cambridge: Polity Press.

Gloria-Palermo, Sandye (1999), The Evolution of Austrian Economics: From Menger to Lachmann, London: Routledge.

Groenewegen, John and Jack Vromen (eds) (1999), Institutions and the Evolution of Capitalism: Implications of Evolutionary Economics, Cheltenham: Edward Elgar.

Groenewegen, John, Christos Pitelis and Sven-Erik Sjöstrand (eds) (1995), On Economic Institutions: Theory and Applications, Aldershot: Edward Elgar.

Hahn, Frank H. (1982), 'The neo-Ricardians', Cambridge Journal of Economics, 6(4), December, pp. 353-74.

Hanusch, Horst (ed.) (1988), Evolutionary Economics: Applications of Schumpeter's Ideas, Cambridge: Cambridge University Press.

Harcourt, Geoffrey C. (1972), Some Cambridge Controversies in the Theory of Capital, Cambridge: Cambridge University Press.

Hobson, John A. (1936), Veblen, London: Chapman and Hall.

Hodgson, Geoffrey M. (1988), Economics and Institutions: A Manifesto for a Modern Institutional Economics, Cambridge and Philadelphia: Polity Press and University of Pennsylvania Press.

Hodgson, Geoffrey M. (1993), Economics and Evolution: Bringing Life back into Economics, Cambridge, UK and Ann Arbor, MI: Polity Press and University of Michigan Press.

Hodgson, Geoffrey M. (1998a), 'The approach of institutional economics', Journal of Economic Literature, 36(1), March, pp. 166-92.

Hodgson, Geoffrey M. (ed.) (1998b), The Foundations of Evolutionary Economics: 1890-1973, 2 vols, International Library of Critical Writings in Economics, Cheltenham: Edward Elgar.

Hodgson, Geoffrey M. (2000), 'What is the essence of institutional economics?', Journal of Economic Issues, 34(2), June, pp. 317-29.

Hodgson, Geoffrey M. (2001), How Economics Forgot History: The Problem of Historical Specificity in Social Science, London and New York: Routledge.

Hodgson, Geoffrey M., Warren J. Samuels and Marc R. Tool (eds) (1994), The Elgar Companion to Institutional and Evolutionary Economics, Aldershot: Edward Elgar.

Hodgson, Geoffrey M. and Ernesto Screpanti (eds) (1991), Rethinking Economics: Markets, Technology and Economic Evolution, Aldershot: Edward Elgar.

James, William (1890), The Principles of Psychology, 1st edition, New York: Holt.

Kirman, Alan P. (1989), 'The intrinsic limits of modern economic theory: the emperor has no clothes', Economic Journal (Conference Papers), 99, pp. 126-39.

Langlois, Richard N. (ed.) (1986), Economics as a Process: Essays in the New Institutional Economics, Cambridge: Cambridge University Press.

Lawson, Tony (1997), Economics and Reality, London: Routledge.

Lazaric, Nathalie and Edward Lorenz (eds) (1998), Trust and Economic Learning, Cheltenham: Edward Elgar.

Lee, Frederick S. (2002), Alfred S. Eichner, Joan Robinson and the Founding of Post Keynesian Economics, Armonk, NY: M.E. Sharpe, forthcoming.

Lukes, Steven (1974), Power: A Radical View, London: Macmillan.

Lundvall, Bengt-Åke (ed.) (1992), National Systems of Innovation: Towards a Theory of Innovation and Interactive Learning, London: Pinter.

Mäki, Uskali (1989), 'On the problem of realism in economics', Ricerche Economiche, 43(1-2), Gennaio-Giugno, pp. 176-98. 
Mäki, Uskali (1992), 'On the method of isolation in economics', in Craig Dilworth (ed.), Idealization IV: Intelligibility in Science, Amsterdam: Rodopi, pp. 317-51.

Metcalfe, J. Stanley (1998), Evolutionary Economics and Creative Destruction, London: Routledge.

Michie, Jonathan and Angelo Reati (eds) (1998), Employment, Technology and Economic Needs: Theory, Evidence, and Public Policy, Cheltenham: Edward Elgar.

Mirowski, Philip (1989), More Heat than Light: Economics as Social Physics, Physics as Nature's Economics, Cambridge: Cambridge University Press.

Mitchell, Wesley C. (1937), The Backward Art of Spending Money and Other Essays, New York: McGraw-Hill.

Neilsen, Klaus and Johnson, Björn (eds) (1998), Institutions and Economic Change: New Perspectives on Markets, Firms and Technology, Cheltenham: Edward Elgar.

Nelson, Richard R. (ed.) (1993), National Innovation Systems: A Comparative Analysis, Oxford: Oxford University Press.

Nelson, Richard R. and Sidney G. Winter (1982), An Evolutionary Theory of Economic Change, Cambridge, MA: Harvard University Press.

Nonaka, Ikujiro and Hirotaka Takeuchi (1995), The Knowledge-creating Company: How Japanese Companies Create the Dynamics of Innovation, Oxford and New York: Oxford University Press.

Nooteboom, Bart (2000), Learning and Innovation in Organizations and Industries, Oxford and New York: Oxford University Press.

Nooteboom, Bart, Hans Berger and Niels G. Noorderhaven (1997), 'Effects of trust and governance on relational risk', Academy of Management Journal, 40(2), pp. 30838.

North, Douglass C. (1990), Institutions, Institutional Change and Economic Performance, Cambridge: Cambridge University Press.

Penrose, Edith T. (1952), 'Biological analogies in the theory of the firm', American Economic Review, 42(4), December, pp. 804-19. Reprinted in Geoffrey M. Hodgson (ed.) (1995), Economics and Biology, Aldershot: Edward Elgar, and in Hodgson (1998b).

Rizvi, S. Abu Turab (1994a), 'The microfoundations project in general equilibrium theory', Cambridge Journal of Economics, 18(4), August, pp. 357-77.

Rizvi, S. Abu Turab (1994b), 'Game theory to the rescue?', Contributions to Political Economy, 13, pp. 1-28.

Salanti, Andrea and Ernesto Screpanti (eds) (1997), Pluralism in Economics: New Perspectives in History and Methodology, Aldershot: Edward Elgar.

Samuels, Warren J. (ed.) (1979), The Economy as a System of Power, 2 vols, New Brunswick, NJ: Transaction.

Saviotti, Pier Paolo (1996), Technological Evolution, Variety and the Economy, Aldershot: Edward Elgar.

Schotter, Andrew R. (1981), The Economic Theory of Social Institutions, Cambridge: Cambridge University Press.

Searle, John R. (1995), The Construction of Social Reality, London: Allen Lane.

Tool, Marc R. (1979), The Discretionary Economy: A Normative Theory of Political Economy, Santa Monica, CA: Goodyear.

Tylecote, Andrew and Jan van der Straaten (eds) (1997), Environment, Technology and Economic Growth, Cheltenham: Edward Elgar.

Veblen, Thorstein B. (1898), 'Why is economics not an evolutionary science?', Quarterly Journal of Economics, 12(3), July, pp. 373-97. Reprinted in Thorstein 
B. Veblen (1919), The Place of Science in Modern Civilisation and Other Essays, New York: Huebsch.

Veblen, Thorstein B. (1899), The Theory of the Leisure Class: An Economic Study in the Evolution of Institutions, New York: Macmillan. Republished 1961, New York: Random House.

Veblen, Thorstein B. (1909), 'Fisher's rate of interest', Political Science Quarterly, 24, June, pp. 296-303. Reprinted in Thorstein B. Veblen (1934), Essays on Our Changing Order, ed. Leon Ardzrooni, New York: Viking Press.

Vining, Rutledge (1949), 'Methodological issues in quantitative economics', Review of Economics and Statistics, 31(2), May, pp. 77-86.

Waldrop, M. Mitchell (1992), Complexity: The Emerging Science at the Edge of Order and Chaos, New York: Simon and Schuster.

Weintraub, E. Roy (1979), Microfoundations, Cambridge: Cambridge University Press.

Williamson, Oliver E. (1975), Markets and Hierarchies: Analysis and Anti-trust Implications: A Study in the Economics of Internal Organization, New York: Free Press.

Witt, Ulrich (ed.) (1992), Explaining Process and Change: Approaches to Evolutionary Economics, Ann Arbor, MI: University of Michigan Press. 
Geoffrey M. Hodgson - 9781843765554

Downloaded from PubFactory at 04/26/2023 10:42:10AM 